This is a self-archived version of an original article. This version may differ from the original in pagination and typographic details.

Author(s): Niles, Spencer G.; Vuorinen, Raimo; Siwiec, Azra Karajic

Title: Training Career Practitioners for the Current Context

Year: 2020

Version: Accepted version (Final draft)

Copyright:

Rights: In Copyright

Rights url: http://rightsstatements.org/page//nC/1.0/?language=en

Please cite the original version:

Niles, S. G., Vuorinen, R., \& Siwiec, A. K. (2020). Training Career Practitioners for the Current Context. In J. A. Athanasou, \& H. N. Perera (Eds.), International Handbook of Career Guidance (pp. 529-553). Springer. https://doi.org/10.1007/978-3-030-25153-6_25 
Running head: Training career practitioners

\section{Chapter 18}

Training Career Practitioners for the Current Context

Spencer G. Niles, Raimo Vuorinen, and Azra Karajic Siwiec 


\title{
Training Career Practitioners for the Current Context
}

\begin{abstract}
Training programs for career practitioners continue to increase in both quantity and quality. For example, international opportunities for those interested in career development facilitator training have increased substantially during the past decade. In this chapter we provide highlights of these developments as they have occurred throughout the world. The chapter details the substantial variability that exists regarding the training career practitioners receive. Finally, we make recommendations regarding minimal training standards and the need for more uniform language within our profession.
\end{abstract}

Keywords: Training, standards, career counselling, career coaching, career practitioner. 


\section{Training Career Practitioners for the Current Context}

Training programs for career practitioners continue to increase in both quantity and quality. For example, international opportunities for those interested in career development facilitator training have increased substantially during the past decade. Additionally, the National Career Development Association (NCDA) in the United States recently created six credentials for career practitioners. The NCDA credentials require particular levels of training and experience for those engaged in providing more basic level career services (Certified Career Services Provider) to master's level career counsellors (Certified Career Counselor) to those who supervise career counsellors (Certified Clinical Supervisor of Career Counseling) to those who train career counsellors (Certified Career Counselor Educator). Each of these credentialing options is intended to increase the professionalism of career practitioners and provide clearer information to consumers regarding the training of those providing various levels of career interventions.

In Europe, the European Lifelong Guidance and Policy Network Guidelines (ELGPN, 2015) emphasise the importance of professionalism and highlight the need for citizens to have confidence that lifelong guidance activities are offered by providers with the knowledge, competence, and ethical standards necessary for competent service delivery. A key element to achieving this level of professionalism is the availability of appropriate training. Like the NCDA credentials, the ELGPN Guidelines support the stipulation of qualifications that ensure that providers have met specific minimum standards of learning and competence.

It is no coincidence that the increasing attention being given to career services comes at a time when the nature of work is changing dramatically. Continued corporate downsizing, emerging technological advances, the relative ease in outsourcing numerous occupations, the 
growing number of dual-career couples, the burgeoning "gig economy", and an expanding contingent workforce all represent changes in the work experience. Each of these changes also presents workers with rather significant career development challenges. Career practitioners must possess the requisite knowledge and skills to address such challenges effectively. Understanding the challenges confronting workers enables practitioners to construct interventions that are relevant to the current context. Thus, training experiences for career practitioners must constantly be updated and adjusted so that trainees have relevant knowledge, awareness, and skills to assist people as they attempt to cope with contemporary career concerns.

Finally, the interaction among career development needs, career development services available, and public policy must be acknowledged. Policy impacts the availability of career services, the training required for competent service delivery, and the availability of that training. Thus, the availability of career services and career practitioner training programs becomes intertwined with national, state/province, and local priorities. Evidence exists, however, that the training and competence of career guidance staff make an essential contribution to the development of high-quality career guidance services, which are essential in meeting the needs of national policy aims (e.g.,Cedefop, 2009, 2011; ELGPN, 2012; Hooley, 2014).

\section{Developing a Common Language in Training Career Practitioners}

There is even a more basic challenge, however, that confronts the career development field. Specifically, the field of career guidance has, for most of its existence, been linguistically challenged. That is, many consumers of career services (and, unfortunately, practitioners) have misused many of the key terms within the field. For example, career services providers occasionally talk about "doing career development" as if "career development" were an intervention rather than the object of an intervention (Herr, Cramer, \& Niles, 2004). Similarly, 
practitioners often confuse the terms "career guidance" and "career counselling." This lack of precision confuses practitioners, students, and clients and, therefore, is a barrier to advancing the efficacy of career development theory and practice globally (often referred to as "Lifelong Guidance" in Europe). When language lacks precision, the implication is that terminology does not matter. However, words have power in that career development practitioners are "engaged in a verbal profession in which words and symbols frequently become the content of the interactions they have with clients" (Herr, 1997, p. 241). Thus, the need exists for greater clarity and specificity with regard to the key terms related to career development interventions. Such specificity enhances the credibility of our profession and provides a common ground for training career guidance practitioners. Developing a common language for the profession enhances the globalisation of training practices and enhances the internationalisation of training opportunities,

In this chapter, key terms are defined as follows:

Career development. This concept refers to the lifelong psychological and behavioural processes as well as contextual influences shaping one's career over the life span. As such, career development involves the person's creation of a career pattern, decision-making style, integration of life roles, values expression, and life-role self-concepts (Niles \& Harris-Bowlsbey, 2017). Ideally these processes lead, in part and with the help of career practitioners, to the development of career management skills or career competence.

Career development interventions. If defined broadly, it involves any activities that empower people to cope effectively with career development tasks (Spokane, 1991). For example, activities that help people develop self-awareness, develop occupational awareness, learn decision-making skills, acquire job search skills, adjust to occupational choices after they have been implemented, and cope with job stress can each be labelled as career development 
interventions. Specifically, these activities include individual and group career counselling, career development programs, career education, computer-assisted career development programs, and computer information delivery systems, as well as other forms of delivering career information to clients.

Career counselling. This involves a formal relationship in which a professional counsellor assists a client, or group of clients, to cope more effectively with career concerns (e.g., making a career choice, coping with career transitions, coping with job-related stress, or job searching). Typically, career counsellors seek to establish rapport with their clients, assess their clients' career concerns, establish goals for the career counselling relationship, intervene in ways that help a client cope more effectively with his or her career concerns, evaluate a client's progress, and, depending on a client's progress, either offer additional interventions or terminate career counselling. Career counsellors often must have advanced training in counselling, psychology, and career development.

Career coaching. Also involves a formal relationship in which a career coach serves as a personal consultant to an individual seeking to deal with work-related concerns such as balancing home, work and career; learning interview skills; strengthening managerial skills; identifying core skills; enhancing personal marketability; and making effective career choices. Career coaches may have advanced training that is similar to the training of career counsellors (career counselling competencies include career coaching) but they may have less training and focus on job search coaching and goal setting rather than the psychological aspects of career decision-making.

Career education. This is the systematic attempt to influence the career development of students and adults through various types of educational strategies, including providing occupational information, infusing career-related concepts into the academic curriculum, offering 
various worksite-based experiences, and offering career planning courses (Niles \& HarrisBowlsbey, 2017). Many educators engage in career education as they incorporate career concepts into subject areas such as mathematics, language arts, and science. Often, those providing career education have minimal training in career development and no training in counselling. In many instances, they work in conjunction with counsellors who possess such training.

Career development programs. These can be defined as "a systematic program of counselor-coordinated information and experiences designed to facilitate individual career development" (Herr, Cramer, \& Niles, 2004, p. 28). These programs typically contain goals, objectives, activities, and methods for evaluating the effectiveness in achieving program goals. Career counsellors can work independently in designing and/or delivering career development programs or as part of a delivery team including other counsellors, career coaches, and/or educators.

Co-careering. The concept of co-careering refers to the shared expertise and meaningful co-construction of career issues among community members in social media. Here, a new competency for career practitioners — an ability to utilise social media for co-construction on cocareering — is linked to creating and maintaining a reliable, properly managed and monitored online presence and participation within the relevant communities in which questions are discussed (Kettunen, 2017).

Defining terms becomes essential for discussing training career guidance practitioners. It clarifies who is being trained to perform what services to which population(s). There is great variation across nations relative to the terminology used to describe career development interventions themselves. Typically, career development interventions address topics such as increasing self-clarity, helping people to acquire skills to connect their self-understanding to work 
opportunities, and coping with transition issues (Niles \& Harris-Bowlsbey, 2017). When coupled with the already existing language differences, the variation in contexts makes communicating about training career practitioners even more challenging. As implied previously, keeping abreast of the various contexts in which people live and in which careers are constructed is an essential task for career practitioners.

\section{International Contexts}

Because contexts vary, career services vary within and across national boundaries. It would be naïve to assume, therefore, that there is, or that there should be, uniformity in the training career practitioners receive. Uniqueness within and across nations requires career practitioners to develop context-specific competencies to respond to their respective settings. What follows is a brief overview of some factors within national contexts that shape career development needs and, therefore, the training required for providing effective career services with specific attention paid to Argentina, Europe, Asia, Australia, South Africa, and North America.

\section{Argentina}

Argentina was significantly impacted by the immigration of Europeans in the $20^{\text {th }}$ century, predominantly from Spain and Italy. In addition, Argentina experiences challenges that are similar to those experienced by many other countries, specifically unemployment, poverty, income distribution inequalities, and the deterioration of social services (Aisenson, de Faletty, \& Del Compare, 1999).

Argentina's Psychological Techniques and Professional Guidance Institute was developed in 1925 and has served as a training institute for guidance counsellors since 1929. Lack of public policies and funding addressing professional guidance limited the growth of 
institutes promoting career services. Despite this, career services have made their way into national universities and high schools in Argentina. In the 1980s and 1990s, career services in Argentina increasingly focused on activities such as developing job search skills and providing job skills training related to occupational areas offering the greatest likelihood for employmentan important response for addressing the country's frictional and structural unemployment. In response to the need of the economically challenged, schools, universities, and hospitals in Argentina provide free guidance programs. In schools, there are counsellors who provide career guidance to students; however, service providers tend not to be trained specifically in career development interventions. In some schools, the responsibility for providing career guidance rests with the teachers.

\section{Brazil}

Privatisation of businesses during the 1990s made changes in the way people managed their careers in Brazil. Careers were tied to organisations and, with privatisation, people's careers became less tied to the organisations and citizens of Brazil became more flexible to changing organisations. Some organisations are now investing energy in developing and retaining talent of their employees as a response to boundaryless careers. In an examination of employees that voluntarily resigned and those who stayed at a company that was purchased and privatised, authors found that both groups in a response to the changing times had a desire towards learning. That is, commitment to own learning and increase in professional development predicated their satisfaction whether they were employed or not. Whether the employees had a secure job with a company who has committed to them or were unemployed, the presence of commitment to education and deeper development is present. Veloso, Dutra, da Silva and Trevisan (2015) warn that security related to jobs, stability, and financial security are not enough of a cushion to 
prevent employees from social pressures such as the changes of privatisation and boundaryless careers.

Latin American countries do not have a well developed vocational guidance system like some European countries. The majority of the focus is on the educational sector where the belief is greatest amount of career guidance takes place. Some authors have called for the development of policies that are about improvement of the functioning of guidance (Mora,2008). Per Gonzales and Ledezema (2009), education in the field of guidance and/or counseling is only existent in Venezuela and Costa Rica. Many academics have called for comprehensive guidance and counselling in schools and what that training may look like however development of comprehensive systems of training skilled career practitioners is still in its infancy.

\section{Europe}

In European countries, the provision of career services is a public interest that transcends education, training, employment and social inclusion policies. In 2004 and 2008, the European Union Member States were invited - in the Council (Education/Youth) Resolutions to improve co-operation and co-ordination on the provision of career guidance services in order to widen access and to ensure coherence of the provision as well as to improve the initial and continuing training of career practitioners (European Commission, 2004, 2008). In 2005, the European Union Member States agreed that the professionalism and qualifications of service providers constitute one of the five quality meta-criteria for national guidance systems. This has led to a significant increase in the development of training programmes and practitioner competence frameworks through EU funded networks among training providers. The competence frameworks intend to offer a generic description which incorporates all of the activities needed to 
deliver coherent career guidance services and can be applied in national contexts in accordance with national policies or accreditation mechanisms (Vuorinen \& Kettunen 2017).

Many European countries provide career services under the umbrella title of the Public Employment Services (PES). The goals of services provided at a PES have traditionally been short-term and oriented toward helping an individual gain employment. Public Employment Services have also helped individuals to gain eligibility for financial support and to access publicly funded training services. More specifically, PES has four identified functions as follows: (a) job broking; (b) labour market information; (c) administering labour market programs (e.g., job search programs; training programs; direct job creation programs); and (d) administering unemployment benefits (Sultana \& Watts, 2006).

In meeting the demands of a rapidly changing world of work, the European Parliament and Council has invited the PES to support initiatives aimed at better skills matching, decent and sustainable work, enhanced self-motivated labour mobility and facilitating the transition from education and vocational training to work. The European Commission Mutual Learning Programme for Public Employment Services, the PES to PES Dialogue program (European Commission, 2014), identified that the skills and competences of employment counsellors are critical for achieving the goals of the European employment strategies. However, there are variations in the entry requirements, competency profiles, and job profiles, as well as in the degree of the flexibility and autonomy of services across countries. The diversification of the job profiles and training of career practitioners depends largely on the operational PES structure, priority tasks, and active labor market programmes used in the country (Sienkiewicz, 2012).

Sessions with PES career practitioners typically range from 45 minutes (Germany) to an hour (Finland). They often include diagnosis in respect to clarifying the individual's concerns, goal 
setting, and developing a plan of action to achieve the identified goals. Career guidance for the employed covers a range of learning activities and products that enable them to take stock of their present work situation (role, conditions, content), the competences they have acquired from work and their validation, and to plan further learning and work transitions, including transitions into retirement. Guidance for unemployed adults refers to a wide range of career counselling activities built on co-construction, by the counsellors and the clients, of the clients' relationship with working life, as well as products that help unemployed jobseekers to improve their employability skills and reintegrate in the labour market. These activities include assessment, profiling or screening, assistance in managing job changes and upskilling, coaching in career management and social skills, job-broking and advocacy, job-search assistance activities, counselling, job club programmes, provision of labour market information, and, if relevant, use of psychometric tests. Employment counselling, a basic service delivered by PES counsellors, is aimed at the sustainable activation and labour market integration (assessment, profiling, etc.) of the unemployed. Specialist career guidance may be provided by PES for those who are seeking a more comprehensive solution; for example,a low-skilled unemployed young person or adult who wishes to pursue a vocational training programme (ELGPN 2015). Individuals requiring more intensive career assistance tend to be referred to staff members with more advanced training in areas such as psychology, education, and sociology.

The question of the future of working life has become an integral part of the career services in PES. Austria, Belgium, the Czech Republic, Denmark, Finland, France, Germany, Hungary, Italy, Norway, Portugal, and Slovakia are some of the countries where substantial labour market information and forecasts are provided to PES clients. PES staff members also visit schools and universities to present information about the labour market. In addition, PES staff members can 
promote individuals' access to experiential and non-experiential forms of labour market information by offering work-experience programs to students to help them become familiarised with the world of work.

Sultana and Watts (2006) have observed four trends related to PES career services as follows: (a) self-service provision; (b) tiering of services; (c) decentralisation from the government; and (d) a move towards outsourcing. Self-service provision involves individuals' use of self-help strategies while having access to career and labour information. Self-help strategies include using career resource centres, self and career exploration packages, web-based job-search resources, and creating one's own web pages for job search purposes. Tiering of services refers to the several levels of career services provided: self-service, group-based services, and intensive case-management. Decentralisation implies that PES is moving away from using federally based employment policies and relying more upon local management and design of services for the implementation of employment policies within regions and provinces. Outsourcing refers to the movement towards being an organisation able to manage specific relations with other agencies to provide services instead of being a largely self-sufficient organisation (Sultana \& Watts, 2006). This implies that the role of PES is shifting to a new role of conductor, enabler and builder of bridges and networks with other service providers. It means adopting a 'co-creation' and continual development approach within PES and with partners, customers, citizens and communities. It also means, increasingly, a shift from service provision to commission and outsourcing of services by PES (Arnkil, Spangar, \& Vuorinen 2017). In this emerging context, practitioners need new competencies to manage their own roles and how they reach out in geographical and professional communities (Cedefop 2009). 
Germany. The largest country in the European Union is Germany with a population of over 82 million. Germany's commitment to their people and vision for people as its greatest wealth is exhibited through their mandated constitutional legislation for education and employment systems within Federal States (Länder). The Federal Government maintains control of vocational training, employment and the labor market, and career guidance is also held under the purview of the Federal Government through the Federal Employment agency (FEA) and municipal Employment Agencies (EA). With globalisation factors, and in view of boundaryless careers, the aim of educational guidance (Bildungsberatung) in the education and vocational guidance (Berufsberatung) in the vocational training and employment is starting to blend due to the desires for lifelong learning of German citizens. All areas of career guidance are working jointly to provide integrated and connected guidance to Germany's citizens.

By law, all students are offered counselling regarding their education, learning difficulties and psychological assessment in school. Those providers are either specialised teachers or social workers, and, when there are needs for psychological assessment, school psychologists fulfill that need through counseling, assessment, and diagnosis of learning-related disorders. As stated earlier, connection with municipal Employment Agencies is emphasised to bring together integrated guidance systems, and, at times, it involves coordinated effort to provide apprenticeship/internships to their students as they work to attain a deeper level of understanding for the world of work prior to graduation.

For career counsellors that are employed by the EA, the knowledge of labor markets, career information systems, the ability to put together career fairs, and provide various vocationally-oriented sessions is important. Career counselors in EA serve as brokers between students and local businesses and trading unions and make recommendations for further career 
related testing and counselling by trained psychologists for their clientele. EA services are provided free of charge and accessible to anyone. Matching job seekers with available local job opportunities is done by placement officers who have gone through minimal competencies of counseling. In longer unemployment periods, citizens are required to undergo counseling to offer broad-based support not just for jobs and training but for financial support as well. In order to offer support to employees' desire for lifelong learning, financial assistance is offered.

Needless to say, career practitioners in Germany have an important role and provide services to a wide range of stakeholders including students, parents,and employers. As a way of offering deeper connections to employers, the German Trade Union Federation has also promoted career guidance by having their own career guidance practitioners, and, through it developed counselling competencies for career guidance practitioners. Providers of career guidance have also grown since the end of the FEA, which allowed municipalities to manage career guidance respective, which, in turn has led to an increase in the number of career practitioners in the private sector.

All in all, while there are aspirational desires for promotion of autonomy, confidentiality and basic requirements regarding use of psychometric assessments, there is no point of agreed upon training and development standards, and organisations such as The German Association for Vocational and Educational Guidance (Deutscher Verband für Bildungs- und Berufsberatung e.V., dvb; http://www.bbregister.de.), The German Association for Counselling (Deutsche Gesellschaft für Beratung e.V.; Essentials für Weiterbildung in Beratung/Counselling; http://www.dachverband-beratung.de.) and the German "Society for Information, Guidance and Therapy at Universities" (GIBeT) offer a training certificate for guidance practitioners in higher education (www.gibet.de/fortbildungszertifikat.html). In addition, the International Association 
for Educational and Vocational Guidance (IAEVG 1995, 2003) ethical standards are also valued. Mandated following of the rules discussed is mainly left in the hands of Länder, regional authorities and municipalities. An important proponent of quality assurance is the German National Guidance Forum in Education, Career and Employment (nfb; www.beratungsqualitaet. net).

The basic premise in training is either Bachelor or Master's level education and, in the cases of providers of career guidance, attention is given to teaching qualifications as well.

Continuing education for career guidance practitioners is offered within their employment site so that there is a greater degree of competence to serve their particular sector respective of the labor market trends for example.

Ireland. In Ireland, compulsory education is from age 6 to 16. Secondary school education is divided into secondary, community and vocational options. Students in their final years of compulsory education mostly chose the leaving certificate program, which allows admittance to higher education and training. Higher education is considered to be universities, institutes of technology, specialisations and private colleges.

Regarding the specific provision of career guidance in the schools, the document entitled Programme Recognition Framework: Guidance Counselling Criteria and Guidelines for Programme Providers (Department of Education and Skills, 2016) offers the following examples of school-based guidance activities:

- Designing, delivering and evaluating guidance learning and developmental programmes relating to personal and social, educational and career development for individual, group and classroom settings;

- Developing effective teaching, learning and assessment strategies for the guidance class; 
- Providing individual and group counselling to facilitate personal and social, educational and career development and at moments of personal crisis;

- Providing labour market, learning and career-related information through Information and Communications Technology (ICT) and blended learning approaches;

- Planning and organising workplace learning and establishing links with the wider business community, agencies and voluntary sector;

- Using psychometric tests (i.e. ability and aptitude tests and career interest inventories) to facilitate career decision-making and personal development, and to support learning and educational choices;

- Working with parents (as appropriate) and referral agencies in facilitating the personal and social, educational and career development of students and service users;

- Referring students and service users to external agencies and professionals, as appropriate; and

- Establishing close ties with feeder schools, where appropriate, and with centres of further education and training and higher education.

The National Training Authority provides career information and guidance services to the public. McCarthy and Coyle (1999) noted that the guidance element of the National Training Authority services is limited. Human resources departments of large organisations are, however, increasingly providing career development training for employees.

When attending the National Training Authority service interview, a job-seeking action plan is developed and put into place. The interviewee is further referred to employment openings or relevant training opportunities. Job seekers may be referred to a local employment service for more intense guidance and counselling, or referred to another relevant agency. The National 
Training Authority worker stays in touch with the job seeker throughout the process to ensure progress and success. Priority is given to job seekers who are unemployed and in a disadvantaged group. Additional services are confidence building and providing resources for intensive job searching.

School-based guidance counsellors must be qualified second-level teachers and, in addition, hold the relevant recognised qualification for school guidance work. The Programme Recognition Framework for Guidance and Counselling in Ireland (Department of Education and Skills, 2016) is a new measure for promoting professionalism in the guidance provision. The framework sets out criteria and guidelines for an initial training program that intends for its program graduates to work in guidance services under the remit of national governmental authorities across the educational and labor market sectors. The intention is that the framework will enable the training providers of initial counsellor training programs to design and deliver career education curricula and sets of learning experiences to equip graduates with the necessary skills and competencies to design and provide quality services in diverse contexts for diverse client groups. The required competency areas cover guidance theories, counselling skills, testing, use of labour market information, communicating, collaborating, networking, research and evidence-informed practice, leading and managing the services. The programs leading to qualifications should meet the minimum level of 60 European Credit Transfer System (ECTS) in guidance and should normally be delivered over one year full-time or two years part-time. A list of programmes that lead to the awarding of such recognised qualifications is available on the National Centre for Guidance Education (NCGE) website (https://www.ncge.ie).

Spain. Spain is a constitutional monarchy with organised autonomous communities, provinces, and municipalities (Hidalgo, Machado, \& Rodriguez, 2002). In 1990, a law was 
passed that came into effect in the 2002/2003 academic year specifying the following (among others): (a) the school-leaving age was changed from 14 to 16 years of age (16 is minimum working age in Spain); (b) providing students who do not obtain a secondary school leaving certificate with a social guarantee program; (c) providing students with vocational training emphasising work-related training and not so much academic focus; and (d) guaranteeing a support system for students.

A training program, passed in 1993, established three subsystems of vocational training as follows: (a) regulated training; (b) occupational training; and (c) continuing vocational training. Regulated training focuses on young people and is governed by the education authorities. Occupational training targets the unemployed providing them with guidance and training to increase employability. Continuing vocational training targets the employed and is governed by employers and unions seeking to provide training in various employment sectors with the goal of raising the qualifications and skills of the employed. Clearly, career practitioners can play vital roles in each of these subsystems.

On a national level, the vocational training program aims to establish a national system of vocational qualifications and provide lifelong learning opportunities. Further, the goal is to provide training to those who leave school prematurely so they can develop increased employability. Spain's vocational training also aims to develop an integrated system of career information and guidance using the European Foundation for Quality Management (EFQM) as a model. There is also a strong emphasis on addressing the career development needs of persons who are members of diverse groups. For example, social guarantee programs target academic failure and dropout problems of people aged 16 to 21 that have limited employability. These 
programs aim to foster the acquisition of the technical knowledge and skills needed to perform a given type of work while also facilitating re-entry into to the educational system.

Nordic Countries. In Nordic countries, the Ministries of Education and Ministries of Labour develop policies for career services and have, to a large extent, been inspired by recent lifelong guidance (LLG) policy development in the European Union and other OECD countries. However, they have followed slightly different, yet complementary, paths in terms of practice, research and policy development. The Nordic co-operation has raised the awareness of the transversal nature of career guidance policies and the common understanding of shared terminology and goals for a coherent national lifelong guidance system.

In all the Nordic countries, there seems to be a consensus on the importance of lifelong guidance as an important vehicle in promoting lifelong learning, labour force development as well as in social equity. Communication with national stakeholders has led to continuous processes of exchange of information on guidance-related initiatives and has resulted in developing measures that make co-operation between ministries more efficient. For example, Norway has established regional career centres for adults, created a compulsory career-learning program in secondary school and developed a new Masters programme in career guidance. Iceland has introduced a universal right to career guidance and promoted outreached guidance services in workplaces. Sweden has been actively developing guidance services for immigrants and refugees. The Nordic Association for Educational and Vocational Guidance is the association in charge of the Nordic career professionals through the development and implementation of professional and ethical standards.

In Finland, career education is a mainstream strategy in education and legally defined student entitlement. Career education is a compulsory element in the curriculum and a continuum from 
comprehensive education to further education. In grades 1-6, guidance is embedded in the work of the classroom teachers. Within career education, the pupils get support in acquiring social skills and team skills, methods in learning, studying as well as seeking and obtaining information. The first years in schools form the basis for transversal life skills and strengthen their positive selfimage as learners. Pupils are encouraged to take responsibility of their daily life, learning, decisions and activities as an active member and actor within their peer group and within immediate surroundings. In secondary level (grades 7-9), the career education comprises altogether 76 hours of scheduled activities in students' timetables over the three-year period. In upper secondary level education, the national core curricula includes two 38-hour compulsory modules of career education. In addition, there is an entitlement for individual guidance and group counselling, and work-experience periods.

In practice, the students examine the links between different school subjects with further studies, entrepreneurship, working life and future skills needs. They learn to use educational and labour market information, advice and guidance services both within one-stop-career centers and within online spaces. Emerging emphasis is on the the use of social media. The students learn to present themselves within online spaces as well as to evaluate the reliability and validity of career information and the various sources of it in the light of career planning. This legally defined time allocation in the core curricula is a cost-effective preventive measure to provide the whole student age cohort with an opportunity for acquisition of lifelong Career Management Skills as an explicit competence of lifelong learning, not only how to make an individual choice of next school level. The school counsellors have the main responsibility of the delivery of career education in cooperation with all staff members. The qualifications and competences of school counsellors are 
regulated: either a Master's degree in school counselling or a 60 ECTS postgraduate diploma is required.

In Denmark, priority is given to educational and vocational guidance for young people. The Danish Act on Guidance aims to develop a transparent guidance system with easy access to high quality guidance services. A National eGuidance (https://www.ug.dk/evejledning/) is a digital guidance service which was launched in 2011 by the Danish Ministry of Education with a view to enhancing and complementing the already existing Youth Guidance Centres and Regional Guidance Centres. This online service can be reached by e-mail, chat, phone, text message or social media seven days a week from morning to evening. eGuidance is for all citizens - young people and adults. The use of virtual communication presents new benefits when compared to more traditional guidance means, including increased flexibility and convenience for users. The services can be reached from all over the country regardless of the geographical location through personal computers or mobile devices all seven days a week. The career practitioners have a specific in-house training to guarantee the consistency in the use of different channels within the service.

\section{Asia}

Career interventions in Asia are just starting to emerge in systematic ways. Asian countries experience the challenge of implementing career services while also coping with substantial cultural shifts currently occurring as a result of factors such as governments democratising, the influx of job opportunities due to other countries engaging in off-shoring, the rise of capitalism, and the questioning of long-held cultural values. Moreover, because many Asians adhere to a strong collectivistic orientation toward career development, career interventions emanating from individualistic worldviews may have little applicability in Asian 
countries. Certainly, theories, interventions, and decision-making models must acknowledge this important cultural distinction.

Currently in Japan there is an increase in unemployment attributed to the economic recession, changes in employees' work values and companies' attitudes toward human resources (Tatsuno, 2002). There are no professional career counsellors (in the Westernised sense of this term) in Japan offering services to public. In elementary schools, teachers have the responsibility of providing career education and each school must appoint a career education supervisor. Even though these roles exist, there is little to no career development training provided by those serving in these roles. A similar case exists in middle and high schools; teachers function as job placement officers. Thus, students are being advised and influenced by those with, at best, minimal training in career interventions. Although there are some graduate courses offered on the topic on career interventions, career consultants are not required to enroll in them (Tatsuno, 2002).

Mizuno, Ozawa, and Matsumoto (2017) note that the Ministry of Health, Labor and Welfare (MHLW) and the Ministry of Education, Culture, Sports, Science and Technology (MECSST) are responsible for career services in Japan and set the standards for career consultants. Candidates wishing to qualify as career consultants must complete a basic educational curriculum of 140 hours addressing topics such as the social meaning of career counseling, career counseling skills, and ethics. Candidates must then pass a written exam, a skills demonstration exercise, and a screening interview. Every five years, career consultants must be re-certified; this involves an additional 38 hours of training (eight hours on subject-area knowledge and 30 hours on skill-related areas). 
Like Japan, the state of career services in China is embryonic. In China, major political shifts are occurring as the country turns from a Marxist perspective of career development toward a system in which the individual must now take responsibility for his or her career development. Training in career development theory and practice is just beginning to emerge (Zhang, Hu, \& Pope, 2002). The training programs that do exist have been influenced by groups such as NCDA (Facilitating Career Development training), the Psychological Assessment Company (PAC) and the Beisen Career Institute (BCI), which each provide training experiences for career practitioners (Jin, 2017).

Career services are most visible in Taiwan within the school system. There is a call for counsellors to become more active with the adults and employee career development. Many corporate employers are establishing career management services within human resources departments. Chang (2002) stated that these programs instituted within human resources departments have a strong Western bias. Additionally, because of the preference for assessment in many Western models of career intervention, Taiwanese people are being administered U.S. instruments without being validated and standardised with that population.

\section{Australia}

Training opportunities, policies and standards for career counsellors are expanding in Australia, in part in response to calls from researchers for career counsellors to serve the career challenges adults experience in managing their careers effectively (Flores, Scott, Wang, Yakushko, McCloskey, Spencer, \& Logan, 2003). Historically, guidance has been located in schools with many students per counsellor ratio (as is the case in many other countries).

The Career Development Association of Australia (CDAA) represents Australia's largest community of career development practitioners, with members in every state and territory and 
across all sectors of the profession. The CDAA is a member of the Career Industry Council of Australia (CICA), which was supported by the Australian government and published the Professional Standards for Australian Career Development Practitioners. The Standards were first established in 2006 with the goals of defining practitioner benchmark standards for career practitioners training and practice. The Standards recognise two levels of career practitioners as follows: (a) Professional career development practitioners; and (b) Associate career development practitioner. Professional career development practitioners have a graduate certificate or a vocational graduate certificate and work in the career development field. Associate career development practitioners work in the career field and have earned a Certificate IV. Key to achieving credentialing is the development of core competencies in the following areas:

1. Career development theory

2. Labour market

3. Advanced communication skills

4. Ethical practice

5. Diversity

6. Information and resource management

7. Professional practice (cica.org.au)

Career practitioners continue growing in numbers and CICA does an outstanding job advancing the professionalisation of, and training opportunities for, career practitioners. Patton (2005) stated that "a small number of tertiary institutions have developed programs designed to specifically prepare career practitioners" (p. 224). This number has increased since 2005. In 
many ways, the development of career education in Australia reflects the same developments taking place in the UK and USA a few decades ago (Patton \& McMahon, 2002).

\section{Career Counselling Training}

Clearly, career services are being provided by a wide range of professionals to a wide range of clients across the lifespan. Although the countries and regions of the world discussed are not necessarily representative of the entire world, they do provide a description of where career services are being delivered (schools, universities, communities, and workplace settings) and by whom (e.g., teachers, career practitioners with minimal training, career practitioners with extensive training, practitioners with no formal training). It is a statement of the obvious to note that it is important that services in each geographic context be as responsive as possible to the career needs of persons living and working there. On some occasions, there may be the need for constructing more unique services to address specific worker situations. Most times, career practitioners will need similar skill sets across settings and contexts. Typically, career services include providing labour market information, offering advice regarding specific training and employment opportunities, and conducting training in job search skills. Although these services are clearly useful, they represent a limited view of the career intervention process that may often translate into providing limited career assistance to students and clients. When these services comprise the totality of the career intervention process, little training is required. Familiarity with labour market resources as well as understanding and being able to communicate essential job search skills become the primary skill sets. Given the complexity of career development in the $21^{\text {st }}$ century, however, broader and more sophisticated competencies are needed to adequately address the career needs of adults, adolescents, and children. The most obvious implication of this is the need to expand training programs to properly prepare practitioners. 
Career counsellor training in the United States, for example, typically requires two years of graduate level education comprising extensive requirements in general counselling skills, multicultural counselling, testing and assessment, group counselling, as well as coursework in career development. The Council for the Accreditation of Counseling and Related Educational Programs (CACREP, 2001), for instance, requires coursework in career development to include studies that provide an understanding of career development and related life factors, including all of the following:

a. career development theories and decision-making models,

b. career, avocational, educational, occupational and labour market information resources, visual and print media, computer-based career information systems, and other electronic career information systems,

c. career development program planning, organization, implementation, administration, and evaluation,

d. interrelationships among and between work, family, and other life roles and factors including the role of diversity and gender in career development,

e. career and educational planning, placement, follow-up, and evaluation,

f. assessment instruments and techniques that are relevant to career planning and decision making, and

g. career counseling processes, techniques, and resources, including those applicable to specific populations. (p. 62)

In many ways, however, the career counselling specialty training in the CACREP Standards (which require two years of full-time post-graduate study to complete) serve as the 
"gold standard" for career counselling training. These Standards, as illustrated in Table 1, include a large set of training requirements:

Table 1

The CACREP Standards for Career Counseling Specialty Training

$\mathrm{N}$

Foundations

A. Knowledge

1. Understands the history, philosophy, and trends in career counseling.

2. Understands the settings for the practice of career counseling, including and public sector agencies and institutions.

3. Understands policies, laws, and regulations relevant to career counseling and career development programs.

4. Understands current ethical issues which affect the practice of career counseling and the use of computer-assisted career guidance systems.

5. Understands professional organizations, competencies, and preparation standards that are relevant to the practice of career counseling and career development programs.

\section{B. Skills/Practice}

1. Demonstrates an ability to explain career development as an integral subset of human development.

2. Demonstrates adherence to ethical codes and standards relevant to the profession of career counseling (e.g., NBCC NCDA, ACA). 
Assessment

G. Knowledge

1. Understands assessment strategies for career development and career counseling programs.

2. Understands bias in assessment and interpretation (including cultural and linguistic characteristics of the clients).

3. Understands assessment selection, ethical practices related to assessment, and its limitations.

H. Skills/Practice

1. Demonstrates an ability to administer, score, and report findings appropriately from career assessments instruments involving issues such as leisure interests, learning style, life roles, self-concept, career maturity, vocational identity, career indecision, work environment preference (e.g., work satisfaction), and other related life style/development issues.

2. Demonstrates an ability to assess conditions of the work environment (such as tasks, expectations, norms, and qualities of the physical and social settings).

3. Demonstrates an ability to identify, select, organize, and provide or arrange for the career and educational components of agency or institutional appraisal service.

Research and Evaluation

I. Knowledge

1. Understands research and evaluation in career counseling and development.

\section{J. Skills/Practice}

1. Demonstrates utilization of various types of research and research designs appropriate to career counseling and development research. 
2. Demonstrates the ability to apply appropriate statistical procedures to career development research.

3. Demonstrates the ability to utilize research findings related to the effectiveness of career counseling interventions and programs.

4. Demonstrates the ability to evaluate the career development program and use the results to effect program enhancement by recommending institutional or agency improvements Program Promotion, Management, and Implementation

K. KnowlUnderstands organizational theories, including diagnosis, behaviour, planning, organizational communication, and management useful in implementing and administering career development programs.

1. Understands the methods of forecasting, budgeting, planning, costing, policy analysis, resource allocation, and quality control.

2. Understands leadership theories and approaches for evaluation and feedback, organizational change, decision-making, and conflict resolution.

L. Skills/Practice

1. Demonstrates the ability to plan, organize, and manage a comprehensive career resource centre.

2. Demonstrates the ability to implement career development programs in collaboration with others.

3. Demonstrates the ability to train others about the appropriate use of technology for career information and planning.

4. Demonstrates the ability to provide effective supervision to career development facilitators at different levels of experience by: 
a. Knowledge of their role, competencies, and ethical standards,

b. Determining their competence in each of the areas included in their certification,

c. Further training them in competencies, including interpretation of assessment instruments, and

d. Monitoring and mentoring their activities in support of the professional career counselor; and scheduling regular consultations for the purpose of reviewing their activities.

5. Demonstrates the ability to initiate and implement a marketing and public relations campaign in behalf of career development activities and services.

6. Demonstrates the ability to analyze future organizational needs and current level of employee skills and develop performance improvement training.

Information Resources and Technology

M. Knowledge

1. Understands education, training, and employment trends; labour market information and resources that provide information about job tasks, functions, salaries, requirements and future outlooks related to broad occupational fields and individual occupations.

2. Understand the resources and skills that clients utilize in life-work planning and management.

3. Understands the community/professional resources available to assist clients in career planning, including job search.

4. Understands methods of good use of computer-based career information delivery systems (CIDS) and computer-assisted career guidance systems (CACGS) to assist with career planning. 
5. Understands various computer-based guidance and information systems as well as services available on the Internet and standards by which such systems are evaluated (e.g., NCDA, ACSCI).

6. Understands characteristics of clients that make them profit more or less from use of technology-driven systems.

\section{N. Skills/Practice}

1. Demonstrates the ability to manage career, educational, and personal-social information resources.

2. Demonstrates the ability to evaluate and disseminate career and educational information. (Adapted from http://www.ncda.org/pdf/counsellingcompetencies.pdf)

When these standards are combined with the general counsellor preparation standards (which are also part of the training program), they arguably represent the most complete set of training guidelines for career practitioners in existence worldwide. Certainly, the CACREP standards for career counsellor training demonstrate substantial increases in the sophistication of career services since their inception nearly 100 years ago.

\section{The Evolution of Training Competencies Required for Career Practitioners}

Regardless of national context, most agree that the contributions of Frank Parsons (1909) serve as the structural framework for conceptualising career development interventions and, thereby, Parsons' work also serves as a framework for training career practitioners. Parsons' tripartite emphasis on self-understanding, occupational knowledge, and "true reasoning" or decision-making guides the efforts of both theoreticians and practitioners internationally. During much of the last century, intervention strategies directed toward increasing self-understanding 
were grounded in a logical positivist orientation to science and resulted in interventions that relied primarily upon the use of standardised career assessments. This orientation objectified clients' characteristics and created an intervention model that some refer to as "test 'em and tell 'em". The strategy placed the career practitioner in the role of expert on multiple dimensions (e.g., with regard to identifying possible assessments, administering assessments, and interpreting assessments). Training for career interventions largely focused on preparing practitioners to use assessments in the career counselling process. Aptitude tests and interest inventories were the primary assessment domains.

The emergence of multicultural interventions and the rise of post-modern orientations have left their mark on career intervention strategies. The objectivist emphasis reflected in logical positivism is being supplemented by elevating subjectivity and perspectivity prized in post-modernism. Interventions focused on the subjective, or meaning-making process, in career interventions require the career practitioner to be a guide rather than an expert. Strategies are coconstructed between career practitioner and the client or student. Practitioners draw upon activities such as card sorts, career laddering techniques, values clarification activities, and narrative elaborations. Practitioner and client collaborate within the intervention process and the client is encouraged to take a significant role in selecting assessments and interpreting their results. Thus, this approach to career intervention requires career practitioners to be trained in counselling skills, the use of formal and informal assessments, and multicultural competencies.

The need to acquire occupational information was supported by the creation of information resources. Largely relying on print materials at first (e.g., career biographies, descriptions of occupational requirements) and then more recently computer-based career information delivery systems, these resources provide important information about the nature of 
work in specific occupations (e.g., training requirements, nature of the work, related occupations, etc.). Practitioners integrated information resources into the intervention process to help clients/students connect self-assessment data with occupational information. Performing this task effectively requires more than simply providing information. Practitioners need to be able to help students/clients turn occupational information into useful data that both inform and stimulate the career exploration process.

Donald Super (1957) provided the impetus for expanding the conceptualisation of career development to include career choice processes rather than only career choice content. Super's developmental model emphasised longitudinal expressions of career development. Noting the need for developing readiness for career decision-making, Super and his colleagues articulated the importance of factors such as planning, exploring, information gathering, decision-making, and reality testing as being critical for preparing for key career decision-making moments. Adapting the work of the German developmental psychologist, Charlotte Buhler (1933), Super described the developmental stages and tasks people tend to encounter as they construct their careers. Super also highlighted the fact that life roles interact and that work does not occur in isolation from other dimensions of human experience. Leisure, homemaking, partner, student, and citizen roles provide examples of other life roles that influence work options and vice versa. Super's developmental stages, tasks, and life role theory segments form the basis for many career guidance programs.

Decision-making models have long been central to the career intervention process. Helping students and clients make decisions has typically meant helping them learn a rational scientific problem-solving approach to career decision-making. Various decision-making models emphasise approaches such as benefit cost analysis, values weighting, and taking a rational 
approach to decision making. Increasingly, intuitive approaches to decision-making are being valued in career development. Practitioners realise that the complexity of career decision-making is difficult to contain within a model that employs only part of the person's experience (i.e., rational thought). Emotions, hunches, instincts, and intuitive sensing, once viewed as poor approaches to making decisions, are now recognised as useful and, more importantly for this chapter, teachable. Strategies such as keeping a journal, meditation, and imagery exercises each contribute to developing intuition, which can influence decision-making.

Regardless of chosen career development or decision theories one common challenge facing trainers, career practitioners and researchers is accepting the information society framework within which we now live and reframing the concepts and constructs of career services and related practices. Career practitioners and especially the trainers of career practitioners need a broader understanding and knowledge of their own conceptions of technology and social media as well as their competency for social media within career services. Kettunen (2017) presents an empirically derived conceptual framework for understanding career practitioners' general approaches to social media and competency for social media. Five identified general approaches encompass passive, information-centred, communication-centred, collaborative career exploration and co-careering approach. The concept of co-careering refers to the shared expertise and meaningful co-construction of career issues among community members as well as to the creating, maintaining and monitoring a reliable online presence within relevant communities. Maintaining an online presence also requires a practical understanding of the means and methods by which this presence is projected to others online. Career services have moved from private to the public sphere and from individual sessions to more collective engagements. Within this approach, the practioner's role has expanded to 
include expertise in managing social spaces, and new technologies have accelerated this process. Practitioners have evolved to agile content experts and network catalysts who participate in a variety of communities and develop meaningful connections among their constituents (Kettunen 2017).

According to Kettunen, Sampson and Vuorinen (2015) success in developing competency for social media in career services is a dynamic combination of cognitive, social, emotional and ethical factors, all of which are interwoven. Trainers of career practitioners must be able to provide learning experiences that help practitioners to extend both their practical and conceptual understanding. That means exposing them to situations that will heighten their awareness of how they currently experience social media and how they might move towards a more advanced approach (Kettunen 2017).

In 2003, the International Association for Educational and Vocational Guidance (IAEVG) developed a set of international competencies for career practitioners. These competencies are very similar to those developed earlier by the National Career Development Association (NCDA) in the United States (the NCDA career counselling competencies were most recently updated in 2009) and the Professional Standards for Australian Career Development Practitioners mentioned previously. There are, however, some important distinctions between the two sets of competencies. The IAEVG competencies (IAEVG, 2003) address (see Table 2) the important area of community capacity building, thereby noting the importance of collaboration between community partners to assess human capital and community needs, as well as developing plans to address the economic, social, educational, and employment goals of the community. The NCDA competencies (NCDA, 2009) (see Table 3) contain sections related to diversity and technology, both critical competency areas for all career 
practitioners. Thus, collectively, the two competency statements (i.e., IAEVG's and NCDA's) provide a comprehensive overview of the knowledge, skills, and awareness career practitioners need in the $21^{\text {st }}$ century regardless of national context.

Table 2

IAEVG Competency Areas

1. Assessment:

2. Educational Guidance

3. Career Development

4. Counselling

5. Information Management

6. Consultation and Coordination

7. Research and Evaluation

8. Programs and Service Management

9. Community Capacity Building

(From http://www.ncda.org/pdf/counsellingcompetencies.pdf)

Table 3

NCDA Competency Areas:

1. Career development theory

2. Individual and group counselling skills

3. Individual/group assessment

4. Information/resources

5. Program promotion, management, and implementation

6. Coaching, consultation, and performance improvement 
7. Diverse populations

8. Supervision

9. Ethical/legal issues

10. Research/evaluation

11. Technology

From http://www.ncda.org/pdf/counsellingcompetencies.pdf

Given the fact that these two competency statements contain significant overlap, it is reasonable to expect that training experiences will expose students to the common areas within both competency statements, if not all areas comprising both statements. Where greater differences likely exist are in the strategies trainers use to help students acquire skills in these areas. For example, training experiences for those seeking the Global Career Development Facilitator credential (offered by the Center for Credentialing and Education in the United States) of the Certified Career Services Provider offered by the National Career Development Association as compared to those seeking a graduate degree in counselling will vary in depth and duration. What seems to be most true is that training is needed to provide career assistance to others in an ethical and professional manner. What is also true is that this training can occur in various formats. For instance, symposia can provide relatively brief opportunities for training in modular form across multiple years. With systematic planning for the symposia meetings and for the time period between symposia, trainers could expose students to the competency areas developed by IAEVG/NCDA. For the time between symposia meetings, training can continue via e-mail and video-conferencing.

Other obvious options include using a distance education format that allows trainees to remain close to their place of residence. Technology for delivering training in this medium is 
now of outstanding quality and many university centres provide access to these opportunities. Additional opportunities such as podcasting provide even greater convenience allowing trainees to participate in training sessions via their personal computers. With options such as these, training can be provided to anyone with computer and Internet access.

Additional training opportunities can occur when universities establish international collaborative relationships. Numerous universities have developed such training opportunities providing international exchanges for students and faculty. Engaging in international collaborations effectively integrate global perspectives pertaining to career development theory and practice. Professional conferences provide multiple opportunities for training and development in career interventions. In this regard, it is worth noting that recently several professional associations have collaborated in co-sponsoring conference experiences highlighting the importance of global interactions in thinking and learning about career development.

\section{Conclusion}

Substantial variability exists regarding the training career practitioners receive. It can be argued that the variability needs to decrease by increasing the minimal training standards required for engaging in providing career services. Minimal training should include exposure to career development theory and practice, assessment, and listening skills. Technology, professional associations, and international collaborations provide important opportunities to advance training for career practitioners. Moreover, those engaged in training and practice of career practitioners need to use language more precisely to increase communication and advance research and practice. There seems to be no legitimate excuse today for situations in which those providing career services have no training in career interventions yet, too often, this is the case. Careers are much too complex to allow this situation to continue. In this regard, the CACREP 
standards for training career counsellors provide a reasonable goal for training guidelines worldwide. 


\section{References}

Aisenson, D., de Faletty, R. M., \& de Del Compare, M. G.(1999). Career development in Argentina. In B. Hiebert \& L. Bezanson (Eds.), Making Waves: Career Development and Public Policy (pp.70-83). Ottawa: The Canadian Career Development Foundation.

Arnkil, R., Spangar, T., \& Vuorinen, R. (2017). Practitioner's toolkit for PES building career guidance and lifelong learning. European Union. doi:10.2767/776182

Buhler, C. (1933). Der menschliche lebenslauf als psychologisches problem [The human lifecourse as psychological issue]. Leipzig: Hirzel.

Cefefop. (2009) Professionalising career guidance. Practitioner competences and qualification routes in Europe. Cedefop panorama series; 164. Luxembourg: Publications Office of the European Union.

Cedefop. (2011). Lifelong guidance across Europe: reviewing policy progress and future prospects. Luxembourg: Publications Office of the European Union.

Chang, D. H. F. (2002). The past, present, and future of career counselling in Taiwan. The Career Development Quarterly, 50(3), 218-224.

Council for the Accreditation of Counseling and Related Educational Programs (2001). CACREP accreditation manual. Alexandria, VA: Author.

Department of Education and Skills. (2016). Programme Recognition Framework: Guidance and Counselling. Criteria and Guidelines for Programme Providers. Department of Education and Skills. Stationery Office: Dublin

ELGPN [European Lifelong Guidance Policy Network]. (2012). Lifelong guidance policy development: A European resource kit. ELGPN Tools No. 1. Saarijärvi, Finland. 
ELGPN [European Lifelong Guidance Policy Network]. (2015). The Guidelines for Policies and Systems Development for Lifelong Guidance: A Reference Framework for the EU and for the Commission. ELGPN Tools No. 6. Saarijärvi, Finland.

European Commission. (2014). European reference competence profile for PES and EURES counsellors, Brussels

European Council. (2004). Draft resolution of the council and of the representatives of the member states meeting within the council on strengthening policies, systems and practices in the field of guidance throughout life in Europe. Council of the European Union, 18 May 2004. Brussels, EU.

European Council. (2008). Draft resolution of the council and of the representatives of the government of the member states, meeting within the council, on better integrating lifelong guidance into lifelong learning strategies. Brussels: EU.

Flores, L. Y., Scott, A. B., Wang, Y., Yakushko, O., McCloskey, C., Spencer, K., \& Logan, S. A. (2003). Practice and research in career counselling and development - 2002. The Career Development Quarterly, 52, 98-131.

Gonzales, B., \& Ledezema, M. (2009). Guidance and counseling in Latin America. General considerations about the criteria of coherence, cooperation and quality. Orientación y Sociedad, 92-100. Retrieved from http://www.scielo.org.ar/scielo.php?script=sci_arttext\&pid=S1851$\underline{88932009000100002 \& \operatorname{lng}=\mathrm{es} \& n \mathrm{~nm}=\mathrm{iso} \& \ln \mathrm{ln}=\mathrm{en}}$

Haas, H. (1999). Career development in Germany. In B. Hiebert \& L. Bezanson (Eds.), Making Waves: Career Development and Public Policy (pp.187-201). Ottawa: The Canadian Career Development Foundation. 
Herr, E. L.(1997). Career counselling: A process in process. British Journal of Guidance and Counselling, 25(1), 81-93.

Herr, E. L., Cramer, S. H., \& Niles, S. G. (2004). Career guidance and counselling through the lifespan. Systematic approaches $\left(6^{\text {th }}\right.$ ed.). New York: Harper Collins.

Hidalgo, C. O., Machado, A. M., \& Rodriguez, C. J. F. (2002). Vocational education and training in Spain. Luxembourg: European Centre for the Development of Vocational Training.

Hooley, T. (2014). The Evidence Base on Lifelong Guidance. A Guide to Key Findings for Effective Policy and Practice. ELGPN Tools No.3. Saarijärvi, Finland

International Association for Educational and Vocational Guidance (2003). International competencies for educational and vocational guidance practitioners. Bern, Switzerland: Author.

Isaacson, L. E., \& Brown, D. (2000). Career information, career counselling, and career development. Boston: Allyn and Bacon.

Jenschke, B., Schober, K., \& Langner, J. (2014). National Guidance Forum in Education, Career, and Employment: Career Guidance in the Life Course: Structures and Services in Germany. DOI: https://www.ssoar.info/ssoar/bitstream/handle/document/52944/ssoar2014-jenschke_et_al-Career_Guidance_in_the_Life.pdf?sequence=1

Kettunen, J. (2017). Career practitioners' conceptions of social media and competency for social media in career services. Jyväskylä, Finland: University of Jyväskylä, Finnish Institute for Educational Research. Studies, 32. Dissertation. http://urn.fi/URN:ISBN:978-951-39$\underline{7160-1}$ 
Kettunen, J., Sampson, J. P., Jr., \& Vuorinen, R. (2015). Career practitioners' conceptions of competency for social media in career services. British Journal of Guidance \& Counselling, 43, 43-56. http://dx.doi.org/10.1080/03069885.2014.939945

McCarthy, J., \& Coyle, B. (1999). Career development services in Ireland. In B. Hiebert \& L. Bezanson (Eds.), Making Waves: Career Development and Public Policy (pp.202-220). Ottawa: The Canadian Career Development Foundation.

Mizuno, S., Ozawa, Y, \& Matsumoto, K. (2017). Career services and professionals in Japan. In H. Yoon, B., Hutchison, M. Maze, C. Pritchard, \& A. Reiss (Eds.) International practices of career services, credentials, and training. Broken Arrow, OK: National Career Development Association.

National Career Development Association (1997). Career counseling competences. Tulsa, OK: Author.

Niles, S.G., \& Harris-Bowlsbey, J. (2017). Career development interventions in the $21^{\text {st }}$ century. Upper Saddle River, NJ: Merrill Prentice Hall.

Organization for Economic Co-Operation and Development (2004). Career guidance and public policy: Bridging the gap. Paris, France: Author.

Parsons, F. (1909). Choosing a vocation. Boston: Houghton Mifflin.

Patton, W. (2005). Coming of age? Overview of career guidance policy and practice in Australia. International Journal for Educational and Vocational Guidance, 5, 217-227.

Patton, W., \& McMahon, M. (2002). Theoretical and practical perspectives for the future educational and vocational guidance in Australia. International Journal for Educational and Vocational Guidance, 2, 39-49. 
Plant, P.( 2003). The five swans: educational and vocational guidance in the Nordic countries. International Journal for Educational and Vocational Guidance, 3, 85-100.

Research Institute of Employment and Vocation (currently, Japan Labor Study Organization). (1989). The international study on job placement: A bridge between school and job. Tokyo, Japan: Research Institute of Employment and Vocation Report, 24.

Sienkiewicz, L. (2012). Job profiles and training for employment counsellors. European Commission. Brussels

Spokane, A. R.(1991). Evaluating career interventions. Englewood Cliffs, NJ: Prentice Hall.

Sultana, R. G., \& Watts, A. G. (2006). Career guidance in public employment services across Europe. International Journal for Educational and Vocational Guidance, 6, 29-46.

Super, D. E. (1957). The psychology of careers. New York: Harper \& Row.

Tatsuno, R. (2002). Career counselling in Japan: today and in the future. The Career Development Quarterly, 50(3), 211-217.

Veloso, E. F. R, Durta, J. L., da Silva, R. C., \& Trevisan, L. N. (2015). Professional transition in Brazil and the need for career vision review. - Journal on Innovation and Sustainability, 6, 2. ISSN: 2179-3565.

Vuorinen, R., \& Kettunen, J. (2017). The European Status for Career Service Provider Credentialing: Professionalism in European Union (EU) Guidance Policies. In H. Yoon, B. Hutchison, M. Maze, C. Pritchard, \& A. Reiss (Eds.) International practices of career services, credentials, and training. Broken Arrow, OK. National Career Development Association. https://www.ncda.org/aws/NCDA/asset_manager/get_file/156343?ver=14

Zhang, W., Hu, X., \& Pope, M. (2002). The evolution of career guidance and counselling in the People's Republic of China. The Career Development Quarterly, 50(3), 226-236. 


\section{Dr. Spencer G. Niles}

Professor and Dean of the School of Education at William \& Mary. Fellow of the American Counseling Association and the National Career Development Association. He is also the recipient of the National Career Development Association's Eminent Career Award, ACA's President's Award, ACA's Thomas J. Sweeney Award for Visionary Leadership and Advocacy, the ACA David Brooks Distinguished Mentor Award, the ACA Extended Research Award, and the University of British Columbia Noted Scholar Award. He is a past-editor for the Journal of Counseling \& Development and The Career Development Quarterly. He is the 2018-2019 President of the National Career Development Association, a Past-President of Chi Sigma Iota and served as President for the National Career Development Association in 2003-2004. He is the author or co-author of approximately 140 publications and has delivered over 150 presentations on career development theory and practice.

\section{Dr. Raimo Vuorinen}

Serves as the Coordinator of the European Lifelong Guidance Policy Network (ELGPN) at the Finnish Institute for Educational Research, in the University of Jyväskylä. In his work, Dr Vuorinen focuses on the strategic design, implementation and evaluation of lifelong guidance services.

\section{Dr. Azra Karajic Siwiec}

Associate Professor of Counselling and Human Development at Walsh University in North Canton, Ohio. She has taught and researched in the area of career development and counselling for more than 10 years. She has co-authored a couple of book chapters and presented at numerous national conferences. She serves as the co-chair of the NCDA Ethics committee. 